\title{
REDUCTION OF PATHOGENIC BACTERIA DURING FERMENTATION OF MASIN BY PROTEASE AND BACTERIOCIN-PRODUCING LACTIC ACID BACTERIA
}

\author{
Heru Pramono $^{1}$ - Taruna Fernando Putra ${ }^{2}$ - Sri Utari ${ }^{2}$ - Novi \\ Andika $^{2}$
}

Ringkasan Contamination of pathogenic and spoilage bacteria on fermentation process of seafood and fisheries product is a major concern on food safety. The aims of this study were isolating and applying the bacteriocin- and protease-producing lactic acid bacteria from the gastrointestinal tract of mud crab for starter culture of masin, a traditional fermented shrimp from East Ja$v a$. This study consisted of characterization of lactic acid bacteria, the application on the fermentation process and microbial analysis. Ninety-four isolates were isolated from mud crab was screened for the bacteriocin and protease producing as well as characterized by $\mathrm{pH}$, salinity and biochemical. Isolate IKP-29 was exhibited strong protease and bacteriocin activity. Application of Isolate IKP-29 on masin fermentation showed that sharp reduction of Escherichia coli, Vibrio sp. and lactic acid bacteria counted. This study suggested that the application of lactic

\footnotetext{
$\left.{ }^{1}\right)$ Departemen Kelautan, Fakultas Perikanan dan Kelautan Universitas Airlangga, Kampus C UNAIR, Jl. Mulyorejo, Surabaya, 60115, Indonesia; ${ }^{2}$ )Program Studi Akuakultur, Fakultas Perikanan dan Kelautan Universitas Airlangga, Kampus C UNAIR, Jl. Mulyorejo, Surabaya, 60115, Indonesia.

E-mail: heru.pramono@fpk.unair.ac.id
}

acid bacteria which producing bacteriocin and protease improved the food safety of traditional fermented fish.

Keywords masin, lactic acid bacteria, fermentation, bacteriocin, protease

Received : 27 Juli 2018

Accepted : 23 Agustus 2018

\section{PENDAHULUAN}

Salah satu permasalahan yang dihadapi terkait keamanan pangan ialah adanya food-borne pathogen seperti Salmonella thypii penyebab demam tifus, Eschericia coli penyebab gangguan pencernaan, maupun Vibrio cholera penyebab kolera. Berbagai upaya untuk mengatasi permasalahan tersebut telah dilakukan, baik berupa preservasi dengan termal maupun non termal. Preservasi pangan tersebut dengan termal dapat berupa pengeringan, pemanasan dan pemasakan maupun dengan non termal seperti ultrasonikasi, tekanan hiperbarik, ionisasi, dan aplikasi biopreservasi. Salah satu metode biopreservasi ialah dengan aplikasi bakteri asam laktat (BAL) penghasil bakteriosin sebagai starter (Hwanhlem et al., 2011) atau- 
pun aplikasi ekstrak bakteriosin pada pangan (Udhayashree et al., 2012).

BAL tersebar luas di alam, termasuk di dalam saluran pencernaan. Saluran pencernaan ikan merupakan ekosistem kompleks yang dihuni oleh mikrobiota, baik mikrobia aerob, fakultatif anaerob maupun obligat anaerob (Talpur et al., 2012). Hal tersebut menyebabkan saluran pencernaan dapat menyimpan potensi kolonisasi bakteri patogen maupun penghasil antibakteri (Sugita et al., 2002).

Isolasi BAL penghasil bakteriosin pada produk fermentasi telah banyak dilakukan (Kopermsub and Yunchalard, 2010; Moroni et al., 2011Moraes et al., 2010Pramono et al., 2015). Talpur et al. (2012) telah melakukan isolasi BAL pada saluran pencernaan rajungan untuk tujuan probiotik. Namun masih sedikit informasi terkait BAL penghasil bakteriosin pada saluran pencernaan kepiting yang diaplikasikan sebagai kandidat starter untuk memperbaiki mutu serta keamanan pangan produk fermentasi.

Scylla sp. merupakan salah satu jenis kepiting yang banyak ditemukan pada ekosistem mangrove Samudra Hindia, Laut Merah, Samudra Pasifik dan termasuk spesies yang paling banyak tersebar di dunia (Shelley and Lovatelli, 2011). Genus Scylla memiliki ciri-ciri sebagai berikut: panjang pasangan kaki jalan lebih pendek daripada capit, pasangan kaki terakhir berbentuk dayung, karapas berbentuk lebar, dilengkapi dengan 3-9 buah gigi anterolateral, ruas dasar dari antena biasanya lebar, sudut anteroexternal seringkali berlobi, flagel kadang-kadang berada pada orbital mata (Fielder and Heasman, 1978).
Kepiting pada ekosistem mangrove memiliki potensi besar untuk menjadi sumber isolasi BAL penghasil bakteriocinlikeuntuk aplikasi pangan sebagai agen biopreservatif sekaligus starter perbaikan mutu produk. Hal ini disebabkan kepiting mampu hidup pada salinitas yang tinggi dan mengkonsumsi detritus sehingga dimungkinkan adanya kolonisasi bakteri pemecah protein yang kuat. Oleh karena itu penelitian ini penting dilakukan untuk mendapatkan kandidat BAL penghasil bakteriosin kuat pada saluran pencernaan kepiting untuk kemudian dimanfaatkan sebagai starter pada produksi fermentasi ikan tradisional.

Tujuan penelitian adalahmendapatkan isolat starter bakteri asam laktat penghasil bacteriocin-like untuk memperbaiki produk fermentasi tradisional dan mendapatkan data karakteristik produk dan keamanan produk fermentasi ikan yang dihasilkan dengan aplikasi starter.

\section{MATERI DAN METODE}

\section{Isolat Bakteri Asam Laktat}

Isolat bakteri asam laktat (BAL) diperoleh dari hasil penelitian sebelumnya. Sebanyak 94 isolat BAL hasil isolasi saluran pencernaan kepiting bakau telah disimpan pada gliserol steril dan disimpan pada suhu $-10^{\circ} \mathrm{C}$ hingga penelitian dilakukan (Pramono et al.., 2015).Sebelum uji dilakukan sebanyak $10 \mu \mathrm{L}$ isolat BAL-gliserol telah dikultur pada $1 \mathrm{~mL}$ de Mann, Rogosa, Sharpe (MRS )broth (Merck, Darmstadt, Jerman) pada suhu $30^{\circ} \mathrm{C}$ selama 48 jam.Bakteri patogen indikator yang digunakan merupakan Vibrio sp. hasil isolasi dari sate kerang (Pramono et al.., 2015)dan E. 
coli ATCC 2595. Bakteri Vibrio sp. dikultur pada medium saline tryptic soya broth $(3 \% \mathrm{NaCl})$, sedangkan E. coli dikultur pada medium tryptic soya broth (Merck, Darmstadt, Jerman). Uji Produksi Enzim Protease

Isolat BAL kandidat starter diuji kemampuan menghasilkan senyawa enzim proteolitik dengan menggunakan media skim milk agar (SMA) (skim milk $2 \%$, agar $1,5 \%$ ) untuk mengetahui aktivitas penghasilan enzim proteolitiknya. Dua puluh mikroliter kultur broth MRS isolat kandidat starter BAL diteteskan pada permukaan media SMA. Plate kemudian diinkubasi pada suhu $37^{\circ} \mathrm{C}$ selama $24 \mathrm{jam}$. Isolat yang mampu mendegradasi protein susu menunjukkan zona jernih di sekeliling koloni. Tiga isolat dengan diameter zona jernih terbesar akan dikarakterisasi lebih lanjut untuk mendapatkan satu isolat kandidat starter fermentasi ikan

\section{Karakterisasi Bakteri Asam Laktat}

\section{- Pengecatan Gram}

Pengecatan Gram dilakukan dengan mengambil satu ose larutan garam fisiologis dan diteteskan di atas gelas preparat kemudian satu ose biakan BAL diratakan diatasnya kemudian difiksasi di atas api bunsen. Setelah terfiksasi berikan Gram A (kristal violet) selama satu menit, bilas dengan air mengalir. Teteskan Gram B (Kalium Iodida) selama satu menit, bilas dengan air mengalir. Setelah itu teteskan Gram C (etanol) selama 30 detik dan bilas dengan air mengalir baru kemudian berikan Gram D (safranin) selama dua menit sebelum diamati di bawah mikroskop. Morfologi sel diamati di bawah lensa mikroskop untuk mengetahui bentuk, ukuran, maupun konformasi sel BAL.

\section{- Uji Oksidasi Fermentasi}

Uji fermentasi dilakukan dengan menggunakan medium O/F. Satu ose kultur BAL diinokulasikan pada medium OF secara aseptis, satu tabung ditutup dengan parafin sedangkan satu tabung ditutup dengan kapas steril. Bakteri yang mampu melakukan oksidasi ditunjukkan dengan warna kuning pada medium OF tanpa parafin sedangkan bakteri yang mampu melakukan fermentasi ditunjukkan oleh warna kuning pada medium OF berparafin.

\section{- Uji Tipe Fermentasi}

Uji tipe fermentasi dilakukan degan dengan cara menginokulasikan $50 \mu \mathrm{L}$ BAL ke dalam medium MRS cair dalam tabung reaksi yang telah dimasukkan tabung durham dan diinkubasi selama 24 jam pada suhu $37^{\circ} \mathrm{C}$. bakteri yang menghasilkan gas dinyatakan heterofermentatif sedangkan yang tidak menghasilkan gas dinyatakan homofermentatif.

\section{- Uji Produksi $\mathrm{H}_{2} \mathrm{~S}$}

Produksi $\mathrm{H}_{2} \mathrm{~S}$ dilakukan dengan menggunakan medium triple sugar iron agar (TSIA). Sebanyak satu ose kultur BAL ditusukkan pada ujung medium TSIA miring dan digoreskan dengan menggunakan jarum inokulasi. Hasil streak diinkubasi pada suhu $30^{\circ} \mathrm{C}$ selama 24 jam dan dilakukan pengamatan. Bakteri yang mampu menghasilkan $\mathrm{H}_{2} \mathrm{~S}$ akan menunjukkan warna hitam pada media TSIA.

\section{- Uji ketahanan Terhadap pH}

Uji fisiologi yang dilakukan adalah uji produksi gas dan uji pertumbuhan pada $\mathrm{pH}$ 1, 3, 5, 7 dan 9. Medium MRS broth diatur $\mathrm{pH}$-nya dengan menggunakan $1 \mathrm{~N} \mathrm{HCl}$ atau $1 \mathrm{~N} \mathrm{NaOH}$ untuk mendapatkan $\mathrm{pH}$ yang sesuai. Sebanyak 
$50 \mu \mathrm{L}$ kultur BAL diinokulasikan pada mikrotube yang telah diisi dengan MRS dengan $\mathrm{pH}$ yang telah disesuaikan, yaitu 1,3,5,7, dan 9 kemudian telah dilakukan inkubasi pada suhu $30^{\circ} \mathrm{C}$ dan dilakukan pengamatan. BAL yang tumbuh menimbulkan media MRS broth menjadi keruh dan setelah diplate pada medium MRS agar menunjukkan tumbuhnya koloni.

\section{- Uji Ketahanan Terhadap Salinitas}

Uji ketahanan terhadap salinitas dilakukan dengan menggunakan medium MRS. Sebanyak $50 \mu \mathrm{L}$ kultur BAL diinokulasikan pada medium MRS broth dengan konsentrasi $\mathrm{NaCl}$ yang berbeda $(1 \%, 2 \%, 3 \%, 4 \%$, dan $5 \%)$ dan diinkubasi pada suhu $30^{\circ} \mathrm{C}$ selama 24 jam.BAL yang tumbuh menunjukkan kekeruhan pada media dan setelah diplate pada medium MRS agar menunjukkan tumbuhnya koloni merupakan bakteri yang tahan terhadap salinitas yang digunakan.

\section{Aplikasi Bakteri Asam Laktat Starter pada Produksi Masin}

\section{- Preparasi masin dan inokulasi star-} ter

Masin diproduksi dengan mencampurkan 400 g udang dengan nasi kering yang telah disangrai sebanyak 120 gram ditambah dengan 400 gram garam dapur, dan $100 \mathrm{~mL}$ air keran. Setelah diaduk merata, bakteri E.coli ATCC 2595, Vibrio sp. dan BAL starter dimasukkan dalam adonan dengan kepadatan 6 log $\mathrm{CFU} / \mathrm{g}$ untuk campuran dari ketiga isolat kuat (IKP-29, IKP-30, dan IKP-94). Proses fermentasi dilakukan pada suhu ruang dan dilakukan pengamatan berupa analisis mikrobiologi dan pengukuran $\mathrm{pH}$ pada jam ke-0, 24, 48, 72, dan 96.
Tabel 1 Diameter zona hidrolisis kasein susu tiga isolat terkuat

\begin{tabular}{lccc}
\hline \multirow{2}{*}{ Isolat } & \multicolumn{3}{c}{ Zona hidrolisis (mm) } \\
\cline { 2 - 4 } & 24 jam & 48 jam & 72 jam \\
\hline IKP29 & 3 & 12 & 12 \\
IKP30 & 5 & 6 & 6 \\
IKP94 & 5 & 7 & 9 \\
\hline
\end{tabular}

\section{- Analisis mikrobiologi}

Analisis mikrobiologi terdiri atas perhitungan jumlah E. coli, Vibrio sp., dan BAL dengan metode TPC pada medium eosin methylene blue agar (EMBA), thiosulfate citrate bile salts sucrose (TCBS), dan de Man, Rogosa dan Sharpe (MRS) agar, secara berurutan.

\section{HASIL DAN PEMBAHASAN}

\section{Uji Produksi Protease}

Sebanyak 94 isolat bakteri asam laktat (BAL) penghasil bakteriosin-like yang telah diuji dengan netralisasi $\mathrm{pH}$ dan uji sumuran terhadap bakteri indikator telah diperoleh dari saluran pencernaan kepiting bakau (Pramono et al., 2015) kemudian telah diuji aktivitas produksi enzim protease. Berdasarkan hasil uji aktivitas proteolitik, tiga isolat yang mampu menghasilkan protease kuat $(>6 \mathrm{~mm})$ pada medium skim milk adalah isola IKP29, IKP30, dan IKP94. Kemampuan bakteri dalam menghasilkan protease ekstraseluler menyebabkan terjadinya lisis pada kasein susu pada medium skim milk agar sehingga terdapat zona jernih disekeliling koloni (Nespolo and Brandelli, 2010). Semakin besar zona yang dihasilkan maka semakin besar aktivitas proteolitik isolat yang diuji. Hasil penelitian menunjukkan bahwa terdapat 3 isolat BAL yang mampu menghasilkan enzim protease $>6 \mathrm{~mm}$ pada jam ke 72 (Tabel 1). 
Enzim protease dihasilkan mikrobia untuk mendapatkan asam amino dan peptida dari hidrolisis protein. Asam amino tersebut digunakan oleh bakteri sebagai bahan penyusun protein seluler, baik fungsional maupun struktural, atau sebagai sumber nitrogen pada sel bakteri (Setyati and Subagiyo, 2012; Remigio et al., 2012).

\section{Karakterisasi Bakteri Asam Laktat Peng-} hasil Protease

Identifikasi BAL didasarkan pada dua metode umum yaitu metode morfologi dan fisiologidan dengan menggunakan metode molekuler (Mohammed et al., 2009) yaitu dengan sekuensing gen $16 \mathrm{~S}$ rDNA. Identifikasi BAL dengan metode morfologi dan fisiologi dilakukan dengan tahapan: pengecatan Gram, bentuk sel, uji motilitas, uji fisiologi dan biokimia (uji katalase, tipe fermentasi, dan pertumbuhan sel pada $\mathrm{pH}$ tertentu).

Hasil pengecatan Gram dan morfologi (Tabel 2) menunjukkan bahwa ketiga isolat merupakan Gram positif. Isolat IKP29 dan IKP94 memiliki bentuk bulat sedangkan isolat IKP30 berbentuk batang pendek. Bakteri asam laktat merupakan kelompok bakteri Gram positif dengan bentuk batang ataupun bulat (Speranza et al., 2017). Beberapa spesies bakteri asam laktat mampu menghasilkan senyawa antimikrobia seperti bakteriosin, hidrogen peroksida, maupun asam organik(Putra et al., 2018).

Hasil uji TSIA menunjukkan bahwa BAL tersebut tidak menghasilkan hidrogen disulfida. Ketiga isolat mampu melakukan fermentasi glukosa dan termasuk dalam katagori BAL homofermentatif yang melakukan fermentasi glukosa menjadi asam laktat.Menurut Saithong et al. (2010)salah satu parameter
BAL dapat dimanfaatkan sebagai kultur starter fermentasi ikan ialah termasuk dalam jenis homofermentatif. Hasil uji oksidase dan katalase menunjukkan ketiga isolat tidak menghasilkan enzim oksidase dan katalase. BAL termasuk dalam ordo Lactobacillales (Ludwig et al., 2015)) yang memiliki ciri: Gram positif, berbentuk batang atau kokus, tidak berspora, non motil, katalase negatif dan oksidase negatif. BAL menggunakan karbohidrat sebagai sumber energi dan menghasilkan asam laktat sebagai produk utama atau satu-satunya fermentasi dan merupakan golongan bakteri fakultatif anaerob (Willey et al., 2009).Bakteri asam laktat termasuk penghasil bakteriosin yang masuk dalam golongan generally recognized as safe (GRAS) oleh WHO sehingga aman digunakan dalam produk pangan.Hasil uji ketahanan terhadap $\mathrm{pH}$ dan salinitas ditunjukkan oleh Tabel 3. Ketahanan terhadap salinitas dan $\mathrm{pH}$ penting kaitannya dengan kemampuan bakteri starter dalam matrik pangan. Berdasarkan hasil uji ketahanan terhadap $\mathrm{pH}$, dapat diketahui bahwa ketiga isolat memiliki rentang ketahanan yang baik pada salinitas dan $\mathrm{pH}$ yang bervariasi. Meskipun demikian, isolat IKP29 memiliki rentang ketahanan yang terbaik terhadap salinitas dan $\mathrm{pH}$ sehingga isolat IKP29 dapat digunakan sebagai kultur starter yang potensial pada produk dengan kadar garam yang tinggi dan $\mathrm{pH}$ yang luas. Hasil identifikasi isolat IKP29 menunjukkan bahwa isolat termasuk dalam Genus Pediococcus.

Aplikasi Bakteri Asam Laktat Starter pada Produksi Masin Analisis mikrobiologi dan $\mathrm{pH}$

Hasil analisis menunjukkan bahwa terjadi penurunan jumlah bakteri yang sig- 
Tabel 2 Hasil uji morfologi dan fisiologi

\begin{tabular}{llcccccccc}
\hline Isolat & Gram & Morfologi & TSIA & Gas & H2S & O/F & Tipe Fermentasi glukosa & oksidase & Katalase \\
\hline IKP29 & Positif & Bulat & - & - & - & F & Homofermentatif & - & - \\
IKP30 & Positif & Batang & - & - & - & F & Homofermentatif & - & - \\
IKP94 & Positif & Bulat & - & - & - & F & Homofermentatif & - & - \\
\hline
\end{tabular}

Tabel 3 Uji salinitas dan ketahanan terhadap $\mathrm{pH}$

\begin{tabular}{lcccccccccc} 
Isolate & \multicolumn{9}{c}{ Salinitas } & \multicolumn{1}{c}{$\mathrm{pH}$} \\
\cline { 2 - 11 } & 1 & 2 & 3 & 4 & 5 & 1 & 3 & 5 & 7 & 9 \\
\hline IKP29 & + & + & + & + & + & - & - & + & + & + \\
\hline IKP30 & + & - & + & + & - & - & - & + & + & + \\
\hline IKP94 & + & + & + & + & + & - & - & - & + & + \\
\hline
\end{tabular}

nifikan pada E. coli dan Vibrio sp. pada hari ke dua dan relatif konstan pada hari ke 3 dan 4 (Gambar 1). Isolat IK29 berdasarkan hasil analisis biokimia dan morfologi merupakan Genus Pediococcus.

Pada awal inkubasi (hari pertama) jumlah bakteri asam laktat dan E.coli dan Vibrio relatif sama, yaitu pada Log 5 $\mathrm{CFU} / \mathrm{g}$, namun pada hari ke-dua terjadi penurunan drastis E.coli dan Vibrio sp. Hal tersebut selaras dengan hasil aplikasi kultur starter bakteri asam laktat pada produksi Plasoom (Saithong et al., 2010). Penurunan bakteri patogen hingga level Log $1 \mathrm{CFU} / g$ mengindikasikan bahwa aplikasi kultur starter bakteri asam laktat dari saluran pencernaan kepiting bakau mampu mempertahankan keamanan pangan produk olahan fermentasi udang yang diproduksi secara tradisional.

Pada awal inkubasi (hari pertama) jumlah bakteri asam laktat dan E.coli dan Vibrio relatif sama, yaitu pada Log 5 $\mathrm{CFU} / \mathrm{g}$, namun pada hari ke-dua terjadi penurunan drastis E.coli dan Vibrio sp. Hal tersebut selaras dengan hasil aplikasi kultur starter bakteri asam laktat pada produksi Plasoom (Saithong et al., 2010). Penurunan bakteri patogen hingga level Log 1 CFU/g mengin- dikasikan bahwa aplikasi kultur starter bakteri asam laktat dari saluran pencernaan kepiting bakau mampu mempertahankan keamanan pangan produk olahan fermentasi udang yang diproduksi secara tradisional.

Penelitian sebelumnya, aplikasi bakteri asam laktat untuk tujuan mereduksi jumlah bakteri patogen pada produk fermentasi Salami, sosis, produk fermentasi ikan juga telah dilaksanakan. Hasil dari aplikasi tersebut adalah penurunan jumlah bakteri potensial patogen hingga level yang dapat diterima (Saithong et al., 2010). Penekanan pertumbuhan bakteri tersebut dimungkinkan karena produksi asam organik oleh bakteri asam laktat yang menurunkan $\mathrm{pH}$ dan menyebabkan pertumbuhan E.coli terganggu (Schnürer and Magnusson, 2005).

\section{SIMPULAN}

Berdasarkan hasil penelitian ini, dapat diketahui bahwa terdapat bakteri potensial kandidat kultur starter fermentasi produk ikan tradisional dari saluran pencernaan kepiting bakau. Hasil aplikasi kultur starter menunjukkan reduksi bakteri E.coli dan Vibrio pada hari ke2 pasca fermentasi sehingga dapat mempertahankan keamanan pangan.

\section{Pustaka}

Fielder, D. and Heasman, M. P. (1978). The mud crab. Queensland Museum. 

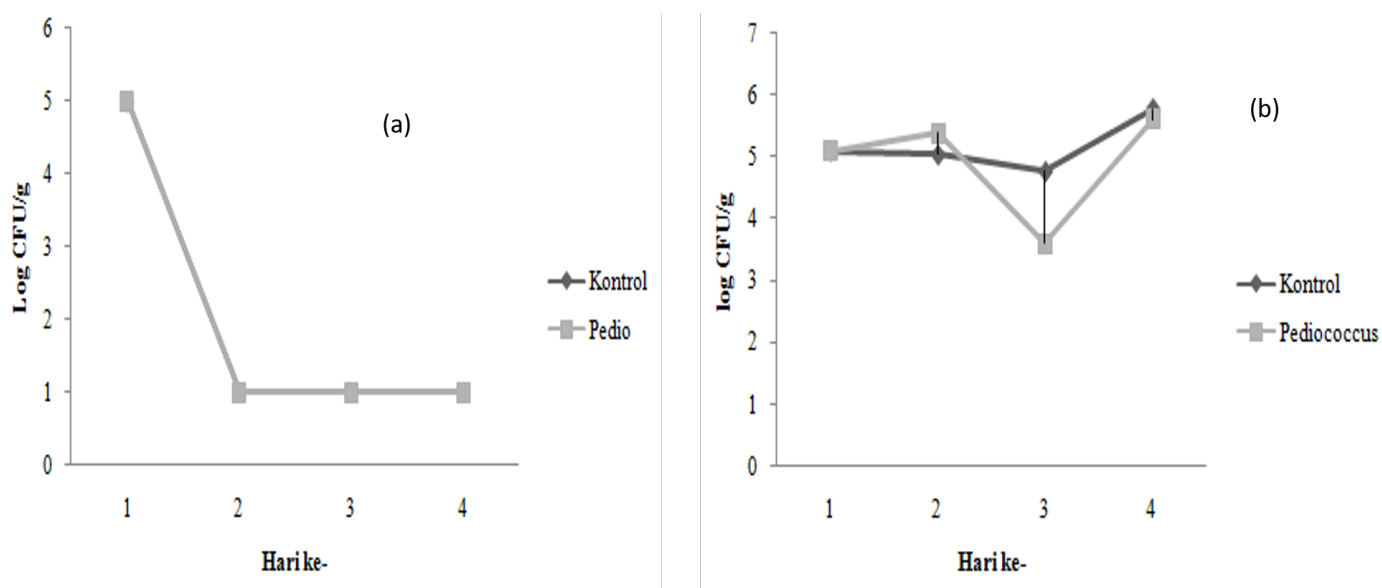

Gambar 1 Hasil perhitungan TPC, (a) Escherichia coli ATCC 2595 dan Vibrio sp.; (b). Bakteri asam laktat

Hwanhlem, N., Buradaleng, S., Wattanachant, S., Benjakul, S., Tani, A., and Maneerat, S. (2011). Isolation and screening of lactic acid bacteria from thai traditional fermented fish (plasom) and production of plasom from selected strains. Food Control, 22(3-4):401-407.

Kopermsub, P. and Yunchalard, S. (2010). Identification of lactic acid bacteria associated with the production of plaa-som, a traditional fermented fish product of thailand. International journal of food microbiology, 138(3):200-204.

Ludwig, W., Schleifer, K.-H., and Whitman, W. B. (2015). Revised road map to the phylum firmicutes. Bergey's Manual of Systematics of Archae a and Bacteria, pages 1-16.

Mohammed, M., El-Aziz, H. A., Omran, N., Anwar, S., Awad, S., and El-Soda, M. (2009). Rep-pcr characterization and biochemical selection of lactic acid bacteria isolated from the delta area of egypt. International journal of food microbiology, 128(3):417-423.

Moraes, P. M., Perin, L. M., Ortolani, M. B. T., Yamazi, A. K., Viçosa,
G. N., and Nero, L. A. (2010). Protocols for the isolation and detection of lactic acid bacteria with bacteriocinogenic potential. LWT-Food Science and Technology, 43(9):13201324.

Moroni, A. V., Arendt, E. K., and Dal Bello, F. (2011). Biodiversity of lactic acid bacteria and yeasts in spontaneously-fermented buckwheat and teff sourdoughs. Food Microbiology, 28(3):497-502.

Nespolo, C. R. and Brandelli, A. (2010). Production of bacteriocinlike substances by lactic acid bacteria isolated from regional ovine cheese. Brazilian Journal of Microbiology, 41(4):1009-1018.

Pramono, H., Suciati, P., and Andriyono, S. (2015). Isolation of lactic acid bacteria that produce protease and bacteriocin-like substance from mud crab (scylla sp.) digestive tract (isolasi bakteri asam laktat yang menghasilkan protease dan senyawa bacteriocin-like dari saluran pencernaan kepiting. ILMU KELAUTAN: Indonesian Journal of Marine Sciences, 20(1):33-37. 
Putra, T., Suprapto, H., Tjahjaningsih, W., and Pramono, H. (2018). The antagonistic activity of lactic acid bacteria isolated from peda, an indonesian traditional fermented fish. In IOP Conference Series: Earth and Environmental Science, volume 137, page 012060 . IOP Publishing.

Remigio, Z., William, M., Olle, H., and Wilson, P. (2012). Isolation and characterization of a protease-producing thermophilic bacterium from an african hot spring. African Journal of Biotechnology, 11(62):12571-12578.

Saithong, P., Panthavee, W., Boonyaratanakornkit, M., and Sikkhamondhol, C. (2010). Use of a starter culture of lactic acid bacteria in plaasom, a thai fermented fish. Journal of bioscience and bioengineering, 110(5):553-557.

Schnürer, J. and Magnusson, J. (2005). Antifungal lactic acid bacteria as biopreservatives. Trends in Food Science \& Technology, 16(1-3):70-78.

Setyati, W. A. and Subagiyo, S. (2012). Isolasi dan seleksi bakteri penghasil enzim ekstraseluler (proteolitik, amilolitik, lipolitik dan selulolitik) yang berasal dari sedimen kawasan mangrove (isolation and selection of extracellular enzyme producing bacteria originating from mangrove sedimen. ILMU KELAUTAN: Indonesian Journal of Marine Sciences, 17(3):164-169.

Shelley, C. and Lovatelli, A. (2011). Mud crab aquaculture: a practical manual. FAO Fisheries and aquaculture technical paper, (567):I.

Speranza, B., Racioppo, A., Beneduce, L., Bevilacqua, A., Sinigaglia, M., and Corbo, M. R. (2017). Autochthonous lactic acid bacteria with probiotic aptitudes as starter cultures for fish-based products. Food microbiology, 65:244-253.

Sugita, H., Okano, R., Suzuki, Y., Iwai, D., Mizukami, M., Akiyama, N., and Matsuura, S. (2002). Antibacterial abilities of intestinal bacteria from larval and juvenile japanese flounder against fish pathogens. Fisheries Science, 68(5):1004-1011.

Talpur, A., Memon, A., Khan, M., Ikhwanuddin, M., Daniel, M. D., and Abol-Munafi, A. (2012). Isolation and screening of lactic acid bacteria from the gut of blue swimming crab, p. pelagicus, an in vitro inhibition assay and small scale in vivo model for validation of isolates as probiotics. Journal of Fisheries and Aquatic Science, 7(1):1-28.

Udhayashree, N., Senbagam, D., Senthilkumar, B., Nithya, K., and Gurusamy, R. (2012). Production of bacteriocin and their application in food products. Asian Pacific Journal of Tropical Biomedicine, 2(1):S406S410.

Willey, J., Sherwood, L., and Woolverton, C. (2009). Prescotts principles of microbiology 2009. 